\title{
International protection of endangered species in the face of wildlife trade: whither conservation diplomacy?
}

\author{
Peter H Sand* \\ Lecturer in International Environmental Law, University of Munich, Germany
}

This article begins with an assessment of an elderly wildife-related treaty, the Convention on International Trade in Endangered Species of Wild Fauna and Flora, 1973 (CITES), and explains both how the convention was originally designed and how its Parties managed to develop it in innovative ways not envisaged by the original drafters. The article then turns to an assessment of the effectiveness of the convention in the modern world, and how an enforcement regime based on trade embargoes has been developed. This success, at least measured by indicators such as length of time it takes for states subject to sanctions to fall back into compliance, aside, the article then proceeds to question effectiveness as measured by indicators with less 'high face validity'. Through close analysis of the history of trade embargoes, it is demonstrated that by and large it is developing countries that have been the subjects of sanctions under CITES. In view of recent enforcement issues (illustrated by current whaling in the North Pacific), the article concludes by highlighting the quality of trust which, it is argued, is a critical requirement that must underpin the international regime if there is to be true legitimacy and, ultimately, credibility.

Keywords: endangered species, CITES, whaling, enforcement, sanctions, legitimacy

\section{INTRODUCTION}

Let me start - as any dyed-in-the-wool environmentalist must - with an alarming bit of news: According to Harvard biologist Edward Wilson, we can now put the fraction of species disappearing each year 'at upward of a thousand times the rate that existed before the coming of humans'. ${ }^{1}$ And at the recent World Conservation Congress of the International Union for Conservation of Nature (IUCN) in Hawaii, in September 2016, he predicted that half of the species described by scientists today will be gone by the end of this century, unless we take drastic action.

Wilson's bold and radical suggestion for a 'global solution to extinction' would be to set aside no less than half of the Earth's habitats (land and sea areas), and thereby preserve about 84 per cent of all living species. ${ }^{2}$ That of course is a tall order, considering that at

* Lecturer in International Environmental Law, University of Munich, Germany. Formerly Secretary-General of the Convention on International Trade in Endangered Species of Wild Fauna and Flora (CITES), Chief of the Environmental Law Unit / United Nations Environment Programme (UNEP), and World Bank Legal Adviser for Environmental Affairs.

1. Edward O Wilson, 'The Global Solution to Extinction', The New York Times Sunday Review (op-ed 12 March 2016).

2. Edward O Wilson, Half Earth: Our Planet's Fight for Life (Liveright/Norton, New York 2016). 
present only some 15 per cent of the world's land and less than three per cent of the oceans are legally protected. ${ }^{3}$ Although Resolution 6.050 of the IUCN World Conservation Congress called for a 30 per cent global target for marine reserves, even that was considered unrealistic by key countries like China, Japan and South Africa. ${ }^{4}$ So in spite of the laudable recent designation of several large marine protected areas (by Australia, France, Mexico, the United Kingdom and the United States, among others), the 'Half-Earth' goal may remain a mirage, and certainly does not acquit us from the duty to make the fullest possible use of other available instruments against the threat of extinction.

There is indeed quite a volume of existing international law in this field. On the one hand, there are 'area-based' conservation accords - first proposed more than a hundred years ago in US President Theodore Roosevelt's (unsuccessful) project of a 'Hague Peace Conference on Nature Conservation' in $1909,{ }^{5}$ and exemplified today by the 1971 Ramsar Convention on Wetlands, ${ }^{6}$ UNESCO's 1972 World Heritage Convention, ${ }^{7}$ the Council of Europe's 1979 Berne Convention, ${ }^{8}$ the series of protected-area protocols adopted under UNEP's regional seas conventions since 1982, ${ }^{9}$ and the 1991 Madrid Protocol for the Antarctic. ${ }^{10}$ On the other hand, there is a wide range of 'species-based' agreements - from the historical bilateral and regional

3. As recorded in the World Database on Protected Areas (WDPA); see Marine Deguignet et al (eds), 2014 United Nations List of Protected Areas (UNEP World Conservation Monitoring Centre, Cambridge 2014), and Nina Bhola et al (eds), Protected Planet Report 2016 (UNEP-WCMC and IUCN World Commission on Protected Areas, Cambridge 2016).

4. Guy Dinmore, 'Conservation Congress Sets Ambitious Target to Protect Oceans', IPS Interpress Service (10 September 2016).

5. Conference invitation letter of 19 February 1909 by US Secretary of State Robert Bacon; Papers Relating to the Foreign Relations of the United States 2 (Department of State, Washington DC 1914). The State Department finally abandoned the project in 1910, after newly elected President William H Taft withdrew his support and dismissed Gifford Pinchot (prime mover of the conference idea under the Roosevelt administration) as head of the US Forest Service. See Sigfried v Ciriacy-Wantrup, Resource Conservation: Economics and Policies (3rd edn, University of California Press, Berkeley 1968) 315-16; Kai Curry-Lindahl, 'Background and Development of International Conservation Organizations and Their Role in the Future' (1978) 5 Environmental Conservation 163-9; Philip Shabecoff, A Fierce Green Fire: The American Environmental Movement (Hill and Wang, New York 1993) 80; and Martin Holdgate, The Green Web: A Union for World Conservation (Earthscan, London 1999) 11.

6. Convention on Wetlands of International Importance Especially as Waterfowl Habitat, adopted at Ramsar on 2 February 1971, 996 UNTS 245.

7. Convention for the Protection of the World Cultural and Natural Heritage, adopted at Paris on 16 November 1972, 1037 UNTS 151.

8. Convention on the Conservation of European Wildlife and Natural Habitats, adopted at Berne on 19 September 1979, 1284 UNTS 209.

9. Protocol concerning Mediterranean Specially Protected Areas, adopted at Geneva on 3 April 1982 (revised 1995); Protocol concerning Protected Areas and Wild Fauna and Flora of the Eastern African Region, adopted at Nairobi on 21 June 1985 (revised 2010); Protocol for the Conservation and Management of Marine and Coastal Areas of the Southeast Pacific, adopted at Paipa on 21 September 1989; and the Protocol concerning Specially Protected Areas and Wildlife of the Wider Caribbean Region, adopted at Kingston on 18 January 1990.

10. Protocol on Environmental Protection to the 1959 Antarctic Treaty, adopted at Madrid on 4 October 1991, 30 ILM 1461. 
treaties for fisheries, seals, polar bears and migratory birds, ${ }^{11}$ to the more recent specific agreements concluded under the 1979 Bonn Convention on Migratory Species. ${ }^{12}$

How effective, then, have these global and regional treaties been 'on the ground'? I shall try to answer this question by analyzing the experience of what is perhaps the most prominent among the species agreements: the 1973 Washington Convention on International Trade in Endangered Species of Wild Fauna and Flora (CITES), ${ }^{13}$ ratified by Australia with effect from 27 October 1976. First, I propose to take a look at the institutional evolution of the CITES regime over the past 40 years (Ed Couzens aptly calls it an 'old watchdog') $;{ }^{14}$ second, at some of its quite remarkable innovations in international treaty practice; and to conclude with a cautionary note on future perspectives, in light of the most recent meeting of its 'Conference of the Parties' (CoP17) held in Johannesburg/South Africa from September to October of 2016. ${ }^{15}$

\section{EVOLUTION OF A TREATY REGIME}

CITES currently has a near-universal membership of 182 contracting States. ${ }^{16}$ It has been described by some as 'perhaps the most successful of all international treaties concerned with the conservation of wildlife'; ${ }^{17}$ although that view is challenged by

11. For an overview see Cyrille de Klemm and Clare Shine, Biological Diversity Conservation and the Law: Legal Mechanisms for Conserving Species and Ecosystems, IUCN Environmental Policy and Law Paper No 29 (IUCN, Gland and Cambridge 1993); and Michael Bowman et al (eds), Lyster's International Wildlife Law (2nd edn, CUP, Cambridge 2010). 12. Convention on the Conservation of Migratory Species of Wild Animals, adopted at Bonn on 23 June 1979, 1651 UNTS 356; on the sub-agreements concluded for seven species between 1990 and 2007, see Alexander Proelss, 'Migratory Species: International Protection' in Max Planck Encyclopedia of Public International Law (Vol 7, OUP, Oxford 2012) 160-9.

13. Adopted at Washington DC, on 3 March 1973, 983 UNTS 243, in response to recommendation 99(3) of the 1972 UN Stockholm Conference on the Human Environment 'that a plenipotentiary conference be convened as soon as possible, under appropriate governmental or intergovernmental auspices, to prepare and adopt a convention on export, import and transit of certain species of wild animals and plants'; Action Plan for the Human Environment, UN Doc. A/Conf. 48/14 of 3 July 1972, p 52. The Convention entered into force on 1 July 1975; amended Appendices I-III are in force as from 2 January 2017 (Notification to the Parties No 2016/068 of 16 December 2016, Annex).

14. Ed Couzens, Whales and Elephants in International Conservation Law and Politics: A Comparative Study (Earthscan, London 2014) 121.

15. World Wildlife Conference (24 September-5 October 2016), with more than 3,500 participants the largest CITES meeting to date.

16. Effective from 8 July 2015, the European Union also became a contracting party, following the entry into force of the 1983 'Gaborone Amendment' of Art XXI on 29 November 2013, and EU Council decision 2015/451 of 6 March 2015; Official Journal of the European Union $2015 \mathrm{~L} \mathrm{75/1}$. On potential legal conflicts arising from the fact that 24 of the 'old' contracting parties (including Japan and the United States) have still not ratified the amendment, see Veit Koester, International Miljøret: Fra Rammerne til Reglerne (Jurist- og Økonomforbundets Forlag, Copenhagen 2016) 394-5 and 826.

17. Simon Lyster, International Wildlife Law: An Analysis of International Treaties concerned with the Conservation of Wildlife (Grotius Publications, Cambridge 1985) 240. See also Barack Obama et al (eds), 'Developments in the Law: International Environmental Law' (1991) 104 Harvard Law Review 1484-639 at 1557; David Harland, Killing Game: International Law and the African Elephant (Praeger, London 1994) 12 ('the most active and visible 
a number of more critical observers, ${ }^{18}$ and the debate continues. ${ }^{19}$ Most of the relevant source material is available online at the Convention's homepage ${ }^{20}$ and in the summary conference reports issued in the Earth Negotiations Bulletin ${ }^{21}$ there even is a semi-fictional novel written about one crucial Conference of the Parties, by Danish writer (and delegate at the time) Hans Helms. ${ }^{22}$ What is beyond dispute is the fact that the practical experience with CITES has indeed provided useful lessons, and in some instances a role model, for other environmental agreements and possibly for the development of modern international environmental law in general. ${ }^{23}$

At the time of its adoption, the Washington Convention was - somewhat hyperbolically - hailed by conservationists as the 'Magna Carta for Wildlife', ${ }^{24}$ and it continues to be abbreviated - somewhat inaccurately - as 'the Endangered Species Convention'. Yet, CITES is definitely not a general-purpose wildlife management treaty. As it stands, it is but one component of the existing patchwork of global and regional regimes for wild animal and plant species, 'laser-focused' ${ }^{25}$ on the single

instrument of international environmental law in force'); P van Heijnsbergen, International Legal Protection of Wild Fauna and Flora (IOS Press, Amsterdam 1997) 27 ('very positive effect on actual fauna and flora protection'); Peter GG Davies, in Bowman et al (n 11) 484 and 533; David M Ong, 'International Environmental Law Governing Threats to Biodiversity', in Malgosia Fitzmaurice et al (eds), Research Handbook in International Environmental Law (Edward Elgar, Cheltenham UK and Northampton MA 2010) 519; and Karin Baakman, Testing Times: The Effectiveness of Five International Biodiversity-Related Conventions (Wolf, Nijmegen 2011) 438.

18. Mark C Trexler, The Convention on International Trade in Endangered Species of Wild Fauna and Flora: Political or Conservation Success? (University of California, unpublished PhD thesis, Berkeley 1990) 99-133 ('symbolic rather than substantial' success); Jon Hutton and Barnabas Dickson (eds), Endangered Species, Threatened Convention: The Past, Present and Future of CITES (Earthscan, London 2000).

19. Michael J Bowman, 'A Tale of Two CITES: Divergent Perspectives upon the Effectiveness of the Wildlife Trade Convention' (2013) 22 Review of European, Comparative and International Environmental Law 228-38; Dan WS Challender et al, 'Towards Informed and Multi-Faceted Wildlife Trade Interventions' (2015) 3 Global Ecology and Conservation 129-48; and Geoffrey Wandesforde-Smith, 'Looking for Law in All the Wrong Places? Dying Elephants, Evolving Treaties and Empty Threats' (2016) 19 Journal of International Wildlife Law and Policy 365-81.

20. Including the quasi-official commentary by former Secretary-General Willem Wijnstekers, The Evolution of CITES: A Reference to the Convention on International Trade in Endangered Species of Wild Fauna and Flora (9th edn, CITES, Geneva 2011), <https://www.cites.org/eng/ resources/publications.php>. See also Peter H Sand, 'Whither CITES? The Evolution of a Treaty Regime in the Borderland of Trade and Environment' (1997) 8 European Journal of International Law 29-58.

21. As for other multilateral environmental agreements, the non-governmental International Institute for Sustainable Development (IISD) has since 2000 provided reporting services covering the CITES meetings; on the 2016 Johannesburg meeting (n 15) see <http://www.iisd.ca/ vol21/enb2197e.html>.

22. Hans J Helms, Dansen i Genève: Fortaellinger fra Verden (Ries, Copenhagen 2004).

23. See Peter H Sand, 'A Century of Green Lessons: The Contribution of Nature Conservation Regimes to Global Governance' (2001) 1 International Environmental Agreements: Politics, Law and Economics 33-72 at 58.

24. Elizabeth N Layne, 'Eighty Nations Write Magna Carta for Wildlife' (1973) 75(3) Audubon Magazine 99; FW King, 'International Trade and Endangered Species' in PJS Olney (ed), International Zoo Yearbook 14 (Zoological Society, London 1974) 2.

25. The term is by political scientist David G Victor (personal communication, 13 September 2016). 
issue of transnational commercial trade (including introduction from the sea), which however is only one of the multiple threats to wildlife (ranging from habitat destruction to pollution and climate change). The treaty does not even control the actual taking of wildlife (capture), ${ }^{26}$ unlike contemporary 'unit management regimes' for fishing, hunting or whaling, ${ }^{27}$ and unlike its historical predecessor, the 1933 London Convention Relative to the Preservation of Fauna and Flora in their Natural State. ${ }^{28}$

On the other hand, the London Convention may be said to have taught the drafters of CITES an important warning lesson to begin with: As an orthodox ad hoc diplomatic instrument, the old treaty had not provided for future intergovernmental decisionmaking or governing institutions, and after two unsuccessful subsequent attempts at adjusting it to changing circumstances (by way of 'technical conferences' in London 1938 and Bukavu 1953) was eventually overtaken by the political events of de-colonization. ${ }^{29}$ Similarly, two regional agreements, which also envisaged trade controls for endangered species but failed to provide the necessary institutional arrangements for implementation, ${ }^{30}$ had remained 'sleeping treaties'. ${ }^{31}$

In light of that sobering historical experience, the authors of the new drafts elaborated between 1967 and $1973^{32}$ opted for an approach that has been described as

26. Eg, a proposal at the 1983 CITES Conference to ban trade in furskins taken by use of steel-jaw leghold traps (considered cruel to animals) was rejected as being beyond the jurisdiction of the treaty; see David S Favre, International Trade in Endangered Species: A Guide to CITES (Nijhoff, Dordrecht 1989) 74.

27. See de Klemm and Shine (n 11) 136.

28. Adopted at London on 8 November 1933, 172 League of Nations Treaty Series 241. See Sherman S Hayden, The International Protection of Wild Life: An Examination of Treaties and Other Agreements for the Preservation of Birds and Mammals, Columbia University Studies in History, Economics and Public Law Nr. 491, 1942 (reprint 2015) 37, 59; and Ed Couzens, 'CITES at Forty: Never Too Late to Make Lifestyle Changes' (2013) 22 Review of European, Comparative and International Environmental Law 311-23 at 315. An earlier 'Convention Designed to Ensure the Conservation of Various Species of Wild Animals in Africa which are Useful to Man or Inoffensive', signed by seven colonial powers at London on 19 May 1900 (French text in 188 Consolidated Treaty Series 418), never entered into force for lack of ratifications; see Couzens (ibid) 312-14; MC Maffei, 'Evolving Trends in the International Protection of Species' (1993) 36 German Yearbook of International Law 131-86 at 134; and Rachelle Adam, Elephant Treaties: The Colonial Legacy of the Biodiversity Crisis (University of New England Press, Hanover, NH 2014) 18-29.

29. Cyrille de Klemm, Conservation et aménagement du milieu: aspects juridiques et institutionnels internationaux, IUCN Supplemental Paper No 19 (IUCN, Morges 1969) 28-9.

30. The Convention on Nature Protection and Wild Life Preservation in the Western Hemisphere, adopted at Washington DC on 12 October 1940, 161 UNTS 193 (Art IX); and the African Convention on the Conservation of Nature and Natural Resources, adopted at Algiers on 15 September 1968, 1001 UNTS 4 (Art IX). The subsequent ASEAN Agreement on the Conservation of Nature and Natural Resources, adopted at Kuala Lumpur on 9 July 1985, Environmental Policy and Law 15 (1986), p 64 (Art V), suffered a similar fate.

31. Term coined by Simon Lyster (n 17) 111, 124.

32. On preparatory work - especially by the International Union for Conservation of Nature (IUCN), the United States and Kenya - see Wolfgand E Burhenne, 'The Draft Convention on the Import, Export, and Transit of Certain Species' (1968) 1 Biological Conservation 61-2; Robert Boardman, International Organizations and the Conservation of Nature (University of Indiana Press, Bloomington 1981) 89; and Barbara J Lausche, Weaving a Web of Environmental Law (Schmidt Verlag, Berlin 2008) 71-80. 
'institutionalizing normative diplomacy', ${ }^{33}$ in the form of a 'dynamic international regime', ${ }^{34}$ with a view to facilitating both the periodic updating of agreed standards (especially the lists of protected species appended to the treaty) and the adoption of agreed implementation measures without requiring renewed ratification.

Among the models for this flexible system of treaty adjustment were provisions to simplify the amendment of 'technical annexes' for the international management of marine living resources (including the 'schedule' of the 1946 Whaling Convention); ${ }^{35}$ for the 'black lists' and 'gray lists' of prohibited or controlled substances in the field of ocean pollution (eg, under the 1972 Ocean Dumping Convention); ${ }^{36}$ and for the listing of internationally protected areas (as under the 1972 World Heritage Convention). ${ }^{37}$ Also 'borrowed' from the whaling regime was the opt-out procedure of CITES Articles XV, XVI and XXIII, which allows dissenting States to enter specific reservations to the listing of species, yet without blocking the rapid amendment of the lists by majority decision. ${ }^{38}$

A number of further adjustments were subsequently introduced - without formal amendment - by consensus or qualified majority decisions of the Contracting Parties, in the form of textual correction, authentic interpretation or temporary suspension of treaty rules. ${ }^{39}$ This continuous 'evolutionary' process has not been uncontested. ${ }^{40}$

33. Yann Kerbrat and Pierre-Marie Dupuy, Droit international public (12th edn, Dalloz, Paris 2014) 408-412 ('institutionnalisation de la diplomatie normative').

34. Thomas Gehring, Dynamic International Regimes: Institutions for International Environmental Governance (Lang, Frankfurt 1994). See also Francesca Romanin Jacur, The Dynamics of Multilateral Environmental Agreements: Institutional Architectures and Law-Making Processes (Editoriale Scientifica, Naples 2013).

35. International Convention for the Regulation of Whaling, adopted at Washington DC on 2 October 1946, 161 UNTS 74. On the relationship with CITES see Ralph U Osterwoldt, International Law and Politics of Conservation: The Case of the Whales (Oxford University, unpublished M Phil thesis 1982) 58-122; Wijnstekers (n 20) 435-9; Couzens (n 14) 155-66; and below notes $115-35$.

36. Convention on the Prevention of Marine Pollution by Dumping of Wastes and Other Matter, adopted at London on 29 December 1972, revised by the Protocol adopted on 24 March 2006, 36 ILM 1 (Art 4).

37. Above (n 7).

38. See the objection procedure of Art V of the Whaling Convention (n 34); Sand (n 20) 40. 39. Eg, see Resolution Conf. 1.5 (1976), endorsing the corrections by Procès verbal communicated by the Depositary Government on 19 March 1976, confirmed by Resolution Conf. 4.6 (Rev. CoP13, 1983/2004); Peter H Sand, 'Endangered Species: International Protection' in Max Planck Encyclopedia of International Law (Vol 3, OUP, Oxford 2013) 423-9 at 424. See also the official definitions of various Convention terms by Resolutions Conf. 4.27 (1983), 5.10 (Rev. CoP15, 1985/2010), 5.11 (1985), 6.7 (1987), 11.11 (Rev. CoP15, 2000/2010), 13.6 (Rev. CoP16, 2004/2013), 14.6 (Rev. CoP16, 2007/2013), and 16.10 (2013); and the tolerated 'sustainable' national export quota for species globally listed on Appendix I, an exception not originally foreseen by the Convention but established by Resolutions Conf. 9.21 (Rev. CoP13, 1994/2004) and 14.7 (Rev. CoP15, 2007/2010); Amanda Wolf, Quotas in International Environmental Agreements (Routledge, London 1997) 96-102; Martijn Wilder, 'Quota Systems in International Wildlife and Fisheries Régimes' in Michael Bothe and Peter H Sand (eds), Environmental Policy: From Regulation to Economic Instruments (Nijhoff, The Hague 2003) 529-81 at 535-49; and Thomas Gehring, 'Treaty-Making and Treaty Evolution' in Daniel Bodansky et al (eds), Oxford Handbook of International Environmental Law (OUP, Oxford 2007) 467-97 at 492 .

40. See the critical comments by Wandesforde-Smith (n 19) and generally Laurence Boisson de Chazournes, 'Environmental Treaties in Time' (2009) 39 Environmental Policy and Law 
On the one hand, there was the controversial practice of controlled auction sales for legally-held ivory stocks; ${ }^{41}$ on the other, there is the equally controversial recent practice of several governments to organize the public burning of those stocks, in desperate reaction to the growing threat of poaching and illegal trafficking. ${ }^{42}$

The governing body in charge of the dynamic adaptation of the Convention to changing circumstances is the Conference of the Parties (CoP), now meeting every three years, with an elected Standing Committee (SC) acting during the intervals. ${ }^{43}$ The permanent institutional structure so established goes far beyond traditional treaty law and may be ranked as a 'comparatively autonomous sectoral legal system'. ${ }^{4}$ Following the 1979 Bonn Amendment in particular, which further enabled the

293-8; Daniel Costelloe and Malgosia Fitzmaurice, 'Lawmaking by Treaty: Conclusion of Treaties and Evolution of Treaty Regimes in Practice' in Catherine Brölmann and Yannick Radi (eds), Research Handbook on the Theory and Practice of International Lawmaking (Edward Elgar, Cheltenham UK and Northampton MA 2016) 111-32 at 123-4. On the relevance of subsequent practice for treaty interpretation in the context of Art 31(3) of the 1969 Vienna Convention on the Law of Treaties (1155 UNTS 331), see G Nolte (ed), Treaties and Subsequent Practice (OUP, Oxford 2013), and the ongoing work of a study group of the UN International Law Commission (ILC) on 'treaties over time'. The second report by Georg Nolte as ILC rapporteur on this topic (UN Doc. A/CN.4/671, 26 March 2014, at pp 36-49), and the ensuing draft conclusions of the Commission at its 66th and 68th sessions in Geneva (UN Doc. A/69/10, 2014, pp 205-17; and UN Doc.A/CN.4/L.874, 2016, p 4), specifically address 'decisions adopted within the framework of a Conference of States Parties'. 41. See Solomon Hsiang and Nitin Sekar, Does Legalization Reduce Black Market Activity? Evidence from a Global Ivory Experiment and Elephant Poaching Data, Working Paper no 22314 (National Bureau of Economic Research, Cambridge, MA 2016); the rebuttal by the MIKE and ETIS Technical Advisory Group, CITES Information Document CoP17 Inf.42 (2016); and the reply by Hsiang and Sekar, CoP17 Inf.96 (2016, submitted by Kenya). After the expiry of a 2007 moratorium for auction sales of legal ivory stocks, CoP17 recommended a general ban of domestic ivory marketing, with a view to preventing poaching and illegal trafficking (Resolution Conf. 10.10/Rev. CoP17, 2016). The Japanese Government, however, declared that it did not consider itself bound by the recommendation, as its domestic ivory market is 'strictly controlled' (Japan Times of 3 October 2016) - a contention vigorously challenged by NGOs; see Environmental Investigation Agency (EIA), The Dirty Secrets of Japan's Illegal Ivory Trade: Japan's Twenty Years of Non-Compliance with CITES Ivory Trade Controls (EIA, Washington DC 2016). A further proposal by 14 African States at $\mathrm{CoP} 17$, to list all elephant species in Appendix I as non-tradeable, failed to obtain the necessary two-thirds majority due to lack of support from the EU delegation; voting records in CoP17 Inf. 93 (2016).

42. See the well-balanced legal analysis by CITES Secretary-General J Scanlon (28 April 2016), available at $<$ https://cites.org/eng/news/pr/kenya_is_set_to_burn_105_tonnes_of_ ivory_what_does_cites_say_28042016>.

43. Formally established by Resolution Conf. 2.2 (1979); currently composed of 16 States selected on a basis of geographical balance, plus the Depositary and the Conference Host States, as laid down in Annex I of Resolution Conf. 11.1 (Rev. CoP17, 2000/2016).

44. Thomas Gehring, 'International Environmental Regimes: Dynamic Sectoral Legal Systems' (1990) 1 Yearbook of International Environmental Law 35-56 at 56. See also Robin Churchill and Geir Ulfstein, 'Autonomous Institutional Arrangements in Multilateral Environmental Agreements: A Little-Noticed Phenomenon in International Law' (2000) 94 American Journal of International Law 623-58; and Peter H Sand, "Le rôle des "conférences des parties" aux conventions environnementales' in Yann Kerbrat et al (eds), Le droit international face aux enjeux environnementaux (Pedone, Paris 2010) 101-08 at 104. 
Conference to adopt financial provisions, ${ }^{45}$ the CITES regime has gradually moved close to the status of an independent international organization, ${ }^{46}$ with concomitant implied powers. ${ }^{47}$

The Conference generally decides by consensus or a two-thirds majority, except for financial matters (three-fourths) and procedural matters (simple majority). ${ }^{48}$ While the international binding force of Conference resolutions has at times been contested by governments (for example, by France - albeit unsuccessfully - in a case before the European Court of Justice in 1990), ${ }^{49}$ and continues to be debated in the literature ${ }^{50}$ most of the evidence of subsequent state practice confirms them as legally binding. ${ }^{51}$ In this regard, CITES may be said to have already taken the quantum leap

45. Protocol to amend Art XI(3) of the Convention, adopted at Bonn on 22 June 1979, in force 13 April 1987, 1459 UNTS 362; see Peter H Sand, “To Treaty or Not to Treaty?" A Survey of Practical Experience' (1993) 87 American Society of International Law: Proceedings $378-83$ at 379.

46. Churchill and Ulfstein (n 44) 658: 'Self-governing treaty-based autonomous institutional arrangements of multilateral environmental agreements may be considered intergovernmental organizations (IGOs), albeit of a less formal, more ad-hoc nature than traditional IGOs'. See also Jacob Werksman, 'The Conference of Parties to Environmental Treaties' in Jacob Werksman (ed), Greening International Institutions (Earthscan, London 1996) 55 and 268; J Sommer, 'Environmental Law-Making by International Organizations' (1996) 56 Heidelberg Journal of International Law 628-67 at 632; PC Szasz, 'The Complexification of the United Nations System' (1999) 3 Max Planck Yearbook of United Nations Law 1-57 at 35; Philippe Sands and Pierre Klein, Bowett's Law of International Institutions (6th edn, Sweet and Maxwell, London 2009) 14; Francesca Romanin Jacur, 'Les Conférences des Parties des conventions internationales de protection de l'environnement en droit international géneral' in Sandrine Maljean-Dubois and Lavanya Rajamani (eds), La mise en æuvre du droit international de l'environnement: Implementation of International Environmental Law (Nijhoff, The Hague 2011) 249-82; Philippe Sands and Jacqueline Peel, Principles of International Environmental Law (3rd edn, CUP, Cambridge 2012) 83.

47. Geir Ulfstein, 'Treaty Bodies' in Bodansky et al (n 39) 877-89 at 881; Ulrich Beyerlin and Thilo Marauhn, International Environmental Law (Hart Publishing, Oxford 2011) 254.

48. Rules of Procedure of the Conference of the Parties (Rev CoP17, 2016), para 26. Until 1985, simple majority decisions had been the rule, except for amendments of the Appendices under Art XV; Wijnstekers (n 20) 353. Since 1994 (CoP9), a distinction is made between 'resolutions' addressed to the contracting parties (currently 95 in force), and 'decisions' addressed to committees or the secretariat (currently more than 70 in force); the categories correspond - if not always consistently - to what Churchill and Ulfstein (n 43) distinguish as 'external' and 'internal' decisions.

49. Regarding Resolution Conf. 5.2 (1985) on trade restrictions for imports from Bolivia; ECJ Case C-182/89 (Commission v France, 'Bolivian furskin case'), judgment of 29 November 1990, European Court Reports [1990] I-4337 at 4344-6. See Ludwig Krämer, European Environmental Law Casebook (Sweet and Maxwell, London 1993) 207-15.

50. Eg, Tim Staal, 'Exercising or Evading International Public Authority? The Many Faces of Environmental Post-Treaty Instruments' (2016) 7:1 Goettingen Journal of International Law 9-48 at 46 ('ambiguous legal status'). See also Wijnstekers (n 20) 353: 'Resolutions and Decisions are non-binding "soft law", their implementation by the individual Parties is subject to their decision to transpose them into national law or not [sic]'; the latter part of the sentence uses language from Conference Decision 9.2 (1994), which however merely stated that 'their implementation by the individual Parties is subject to the procedures required under their national legislation' (emphasis added).

51. Gehring (n 41) 492 ('decisions that are apparently intended to, and seem to be regarded as, legally binding'). Both the European Court of Justice and the US Court of Appeals for the District of Columbia have treated CITES Conference resolutions as authentic treaty interpretation 
from a quasi-contractual to a quasi-legislative process ('de facto law-making', 'droit dérivé'), ${ }^{52}$ which other environmental treaty regimes still hesitate to acknowledge. ${ }^{53}$ That momentous progression, from a one-time law-making agreement to a long-time law-making institution, is also reflected in the treaty's application and implementation in practice.

\section{INNOVATIONS IN TREATY PRACTICE}

Wild animals and plants, like all biological natural resources, are subject to the sovereignty of States within their territory. ${ }^{54}$ This traditional rule of customary international law, which received its official environmental blessing in Principle 21 of the 1972 Stockholm Declaration on the Human Environment, ${ }^{55}$ was reiterated in the preamble of CITES in $1973,{ }^{56}$ and can already been found 40 years earlier in the 1933 London Convention. ${ }^{57}$

Yet, the historical and geographical background in 1933 had been entirely different. The contracting parties at that time were colonial powers, whose sovereign territories included both the areas of origin and the areas of consumption of the natural resources

(above note 41) by the contracting parties; see the judgments in Nilsson (23 October 2003, ECJ (6th Ch) Case C-154/02, European Court Reports [2003] I-12733, para 39), and in Castlewood Products v Norton (30 April 2004, DC Cir Case 03-5161, 365 F.3d 1076, para 44).

52. Jutta Brunnée, 'Reweaving the Fabric of International Law? Patterns of Consent in Environmental Framework Agreements' in Rudiger Wolfrum and Volker Röben (eds), Developments of International Law in Treaty Making (Springer, Heidelberg 2005) 101-26 at 115; Geneviève Bastid-Burdeau, 'Quelques remarques sur la notion de droit dérivé en droit international' in Nicolas Angelet et al (eds), Droit du pouvoir, pouvoir du droit: Mélanges offerts à Jean Salmon (Bruylant, Brussels 2007) 161-75.

53. See Jutta Brunnée, 'COPing with Consent: Law-Making Under Multilateral Environmental Agreements', (2002) 15 Leiden Journal of International Law 1-52; Ellen Hey, 'Sustainable Development, Normative Development and the Legitimacy of Decision-Making' (2003) 34 Netherlands Yearbook of International Law 3-53 at 50; Annecoos Wiersema, 'The New International Law-Makers? Conferences of the Parties to Multilateral Environmental Agreements' (2009) 31 Michigan Journal of International Law 231-87; Michael Bowman, 'Beyond the "Keystone" COPs: The Ecology of Institutional Governance in Conservation Regimes', (2013) 15 International Community Law Review 5-43; Malgosia Fitzmaurice, 'Law-Making and International Environmental Law: The Legal Character of Decisions of Conferences of the Parties' in Rain Liivoja and Jarna Petman (eds), International Law-Making: Essays in Honour of Jan Klabbers (Routledge, London 2014) 190-210.

54. See generally Nico Schrijver, Sovereignty Over Natural Resources: Balancing Rights and Duties (CUP, Cambridge 1997).

55. 'States have, in accordance with the Charter of the United Nations and the principles of international law, the sovereign right to exploit their own resources pursuant to their own environmental policies...'; UN General Assembly Resolution 2294 (XXVII), 11 ILM 1416 (emphasis added). See also Art 3 of the 1992 Convention on Biological Diversity adopted at Rio de Janeiro on 5 June 1992, 1760 UNTS 79, and its preamble: 'Reaffirming that States have sovereign rights over their own biological resources' (emphasis added).

56. 'Recognizing that peoples and States are and should be the best protectors of their own wild fauna and flora'; above n 12 (emphasis added).

57. Above (n 28) Art 9(6): 'All trophies of animals found dead, or accidentally killed, or killed in defence of any person, shall, in principle, be the property of the Government of the territory concerned' (emphasis added). 
concerned. ${ }^{58}$ Hence the enactment and implementation of the necessary hunting, harvesting and customs controls merely required a partial harmonization of their national colonial policies and regulations. ${ }^{59}$ That situation changed radically in the wake of decolonization after the Second World War. From now on, two 'camps' of independent States confronted each other as producers and consumers of the resources at stake ${ }^{60}$ and sovereign rights of access and control became part of the North-South debate over a New Economic Order, under the slogan of 'permanent sovereignty over natural resources' ${ }^{61}$

In this context, a definition in Article $\mathrm{I}(\mathrm{b})$ of the Convention is important: While any individual 'specimen' of a protected species is subject to the sovereign control of the State concerned, ${ }^{62}$ that does not apply to the 'species' itself; ie, the abstract biological genotype to which the specimen belongs. Hence species that are internationally listed as endangered may very well be viewed as (non-renewable) common resources. ${ }^{63}$ Accordingly, State authorities apply the treaty not only by virtue of their own sovereign powers over the specimens or populations of animals or plants concerned, but act at the same time as agents or trustees mandated by the international community to protect the species as a whole. ${ }^{64}$ This dual function of national authorities has indeed been described as a kind of role-splitting ('dédoublement fonction$n e l$ ', in Georges Scelle's celebrated term) ${ }^{65}$ In fact, the CITES regime operates on the basis of mutual recognition of national administrative acts (export/import permits, captive breeding or ranching certificates, etc), issued in accordance with agreed

58. The subsequent extension of the Convention's scope of application to Aden, India and Indonesia was also made under colonial rule; see Hayden (n 28) 59.

59. See generally William M Adams, 'Nature and the Colonial Mind' in William M Adams and Martin Mulligan (eds), Decolonizing Nature: Strategies for Conservation in a Post-Colonial Era (Earthscan, London 2003) 16-50; and Adam (n 28).

60. Note, however, that the confrontation here is not solely one between developed and developing countries. Canadian sealskins for Europe, European falcons for the Gulf States, and especially ivory tusks and rhino horns for East Asian markets illustrate the global trade flows in all directions. See Ginette Hemley (ed), International Wildlife Trade: A CITES Sourcebook (Island Press, Washington DC 1994); and Sara Oldfield (ed), The Trade in Wildlife: Regulation for Conservation (Earthscan, London 2003).

61. See A Diaz, 'Permanent Sovereignty over Natural Resources' (1994) 24 Environmental Policy and Law 157-73.

62. 'Any animal or plant, whether alive or dead', and 'any readily recognizable parts or derivatives thereof'; on the interpretation of those terms by various $\mathrm{CoP}$ resolutions see Wijnstekers (n 20) 53-8, and David S Favre, International Tade in Endangered Species: A Guide to CITES (Nijhoff, Dordrecht 1989) 12-25.

63. Eg, see Michael J Glennon, 'Has International Law Failed the Elephant?' (1990) 84 American Journal of International Law 1-43 at 28, 34 ('global environmental resources'). See also the term 'international resource' for migratory waterfowl, in the preamble of the Ramsar Convention (n 6); PF Mercure, 'La proposition d'un modèle de gestion intégrée des ressources naturelles communes de l'humanité' (1998) 36 Canadian Yearbook of International Law 41-92 at 64; and Chris W Wold, 'World Heritage Species: A New Legal Approach to Conservation' (2008) 20 Georgetown International Environmental Law Review 337-96.

64. Peter H Sand, 'Sovereignty Bounded: Public Trusteeship for Common Pool Resources?' (2004) 4 Global Environmental Politics $47-71$ at 52-3.

65. Cyrille de Klemm, 'Conservation of Species: A New Approach' (1982) 9 Environmental Policy and Law 117-28 at 124; and Cyrille de Klemm, 'Le patrimoine naturel de l'humanité' in Rene-Jean Dupuy (ed), L'avenir du droit international de l'environnement: The Future of the International Law of the Environment (Nijhff, Dordrecht 1985) 117-46 at 139. See Georges 
common standards. The international secretariat in Geneva merely serves as a coordinating switchboard for the decentralized network so established.

How effective, then, has this system been in practice? 'Effectiveness' of course is a notoriously elusive concept, meaning different things to lawyers, economists and political scientists. ${ }^{66}$ So let me start out with a personal memory, from the days when I began to work as the first Secretary-General of CITES, at Morges/Switzerland in the 1970s. ${ }^{67}$

One of our early ways of verifying governmental compliance with CITES was the 'cactus test' - originally thought up by John A Burton, one of the co-founders of TRAFFIC ('Trade Records Analysis of Flora and Fauna in Commerce'). ${ }^{68}$ Why cactus? All wild cactus plants (Cactaceae spp) are listed on Appendix II of CITES, and hence require an export permit to travel abroad, or suitable proof that they are exempt, eg as artificially propagated specimens. So we went into a department store in Morges, and for five Swiss francs acquired a pretty red-flowered cactus advertised as 'Little Red Riding Hood'. From then on, whenever a CITES staff member went on duty travel, he/she had to take the cactus along. Upon arrival at any destination airport in a CITES member country, he/she would proceed through the red entry gate - instead of the green 'nothing-to-declare' entrance - and innocently ask the customs officer whether and how this plant, purchased in Switzerland, should be declared for import.

The reactions at most airports were amazing, and often hilarious. In those days, very few customs inspectors had ever heard of CITES, let alone that their government had ratified the treaty and regularly reported that it was in full compliance with its terms. Their usual reaction was to consult the applicable code of the Customs Cooperation Council (now the World Customs Organisation), define the cactus as 'noncommercial import of an ornamental plant', and wave the nosy passenger on. When the passenger insisted on a document, they would either grab some form and stamp it - we built up the most peculiar collection of so-called import documents - or come up with highly ingenuous authoritative explanations why no form was required in this particular case.

Others would proceed to a phytosanitary inspection, including the occasional fumigation - one customs officer at Copenhagen airport informed me that he was far more concerned about the earth in the flowerpot than about the cactus, and returned Little

Scelle, Précis de droit des gens: principes et systématique (Vol I, Paris, Sirey 1932) 43; and Antonio Cassese, 'Remarks on Scelle's Theory of "Role Splitting" (dédoublement fonctionnel) in International Law' (1990) 1 European Journal of International Law 210-31.

66. See Oran R Young, Marc A Levy and Gail Osherenko, 'The Effectiveness of International Environmental Regimes' in OR Young (ed), The Effectiveness of International Environmental Regimes: Causal Connections and Behavioral Mechanisms (MIT Press, Cambridge MA 1999) $1-32,3$.

67. The narrative which follows is based on an article, 'CITES and the Migratory Cactus' (October 1998) 29(3-4) World Conservation 23-4.

68. Initially a small IUCN Specialist Group set up in 1976, which has since developed into a worldwide NGO network co-sponsored by IUCN and WWF, with offices in 16 countries in Africa, America, East and Southeast Asia, Eastern and Western Europe; see <http://www.traffic.org>; Sand (n 20) at 49-51; John Lanchbery, 'Long-Term Trends in Systems for Implementation Review in International Agreements on Fauna and Flora' in DG Victor, K Raustiala and EB Skolnikoff (eds), The Implementation and Effectiveness of International Environmental Commitments (MIT Press, Cambridge MA 1998) 57-87 at 70-1; Patricia Birnie, Alan Boyle and Catherine Redgwell, International Law and the Environment (3rd edn, OUP, Oxford 2009) 687-8. 
Red Riding Hood naked, without her pot. Once, when travelling to the 1978 IUCN General Assembly in Ashkhabad with other staff members and walking through the red gate at Moscow airport (even though the others had implored me not to do it lest we all end up in a gulag), I was kept in custody for an hour until the competent official showed up and allowed me, exceptionally, to move on with the cactus, in the interest of international ecological cooperation and in order not to miss my connecting flight.

In each case, the cactus-bearing staff member had to write a full report on his/her experience, for transmission and follow-up action to the national CITES authority concerned. As time went by, more and more customs services did become familiar with the Convention, and many international airports became cactus-proof or at least cactuswise. Yet any customs officer who then proudly produced a copy of the treaty text, plus the appropriate form, still faced the problem of identifying the specimen at hand. He/she would study the plant intently, ask for her name, enter 'Little Red Riding Hood' in the column for species nomenclature, perhaps declare her exempt as a household item, and mumble something about the new green bureaucracy. One obvious risk was to hit upon the same embarrassed customs inspector twice in a row - as happened to me at my hometown airport in Munich: What that Bavarian customs officer asked me to do with that cactus (in the native Bavarian dialect) is unfit for print, and therefore could not be fully included in my report to the national CITES authority.

Those of course were the early days of CITES. The secretariat's cooperation with customs services has since evolved worldwide. Under a 1996 Memorandum of Understanding with the World Customs Organization (WCO), ${ }^{69}$ the WCO 'harmonized system' of standard tariff classifications for import/export has been aligned with CITES documentation requirements; joint training and capacity-building programmes now support customs administrations in dealing with illegal wildlife trade. ${ }^{70}$ Moreover, in stark contrast to former years, membership of the Convention is now near-universal, leaving virtually no loopholes for 'free-riding' by non-member countries which until the 1990s had served as lucrative trade havens outside the CITES regime. ${ }^{71}$ In this regard, Article X requiring 'comparable' documentation also for trade with third-party States ultimately proved effective in inducing the 'hold-outs' to join, thus turning free-riders into 'forced riders' ${ }^{72}$

Today instead, the genuine free-riders are Member States that fail to comply with their obligations under the Convention, and exploit the resulting inequality of trading standards to their own competitive advantage. ${ }^{73}$ In response, the CoP developed since 1992 a list of basic criteria for domestic implementing legislation that must be met by

69. See John Lanchbery, 'The Convention on International Trade in Endangered Species of Wild Fauna and Flora (CITES): Responding to Calls for Action from Other Nature Conservation Regimes', in Sebastian Oberthür and Thomas Gehring (eds), Institutional Interaction in Global Environmental Governance (MIT Press, Cambridge MA 2006) 157-80 at 162-4.

70. See also CITES cooperative arrangements with the International Criminal Police Organization (INTERPOL) and the UN Office on Drugs and Crime (UNODC), in the context of the 'International Consortium on Combating Wildlife Crime' (ICCWC); JL Lemahieu and A Me (eds), World Wildlife Crime Report: Trafficking in Protected Species (UNODC, New York 2016).

71. Case histories in Rosalind Reeve, Policing International Trade in Endangered Species: The CITES Treaty and Compliance (Earthscan, London 2002) 129-33.

72. The term is by CS Pearson, Economics and the Global Environment (CUP, Cambridge 2000) 280.

73. Peter H Sand, 'Enforcing CITES: The Rise and Fall of Trade Sanctions' (2013) 22 Review of European, Comparative and International Environmental Law 251-63 at 254. On the need for coercion to prevent this kind of free-riding, see A d'Amato, 'The Coerciveness of International Law' (2009) 52 German Yearbook of International Law 437-60 at 437. 
all Member States in order to satisfy the treaty's requirements: (i) designation of national CITES management and scientific authorities; (ii) prohibition of trade in violation of the Convention; (iii) penalization of such trade; and (iv) confiscation of illegally traded or illegally possessed specimens. ${ }^{74}$ States are periodically grouped in one of three categories: (1) meeting all four requirements; (2) meeting only some of the requirements; or (3) not meeting the requirements. ${ }^{75}$

Given that some at least of the compliance deficits so identified are attributable to problems of administrative capacity - especially in countries lacking the necessary infrastructure in this field ${ }^{76}$ - the Conference initiated a 'carrot and stick' strategy with regard to States ranked in categories 2 and 3. On the one hand, externally funded technical and financial assistance is provided for training and capacity-building, ${ }^{77}$ including specific projects financed by the Global Environment Facility (GEF). ${ }^{78}$ On the other hand, the CoP has since 1985 developed a unique scheme of "collective retorsion' to sanction persistent non-compliance by States, ${ }^{79}$ consolidated and codified in 2007 by Resolution 14.3 ('CITES Compliance Procedures'), ${ }^{80}$ which can be summarized as follows:

(a) when the Secretariat receives information about a case of non-compliance, it provides the information to the Party concerned (paragraph 16);

(b) if the Party fails to take sufficient remedial action within a reasonable time limit, the Secretariat brings the matter to the attention of the Standing Committee (paragraph 21), which may issue a written caution or warning letter, request

74. National Laws for Implementation of the Convention, Resolution Conf. 8.4 (Rev. CoP15). See R Wolfrum, 'Means of Ensuring Compliance with and Enforcement of International Environmental Law' (1989) 272 Hague Academy of International Law: Collected Courses 9-154 at 50 (n 99); and Reeve (n 71) 134-47.

75. As of August 2016, the secretariat (in consultation with the States concerned) ranked 52.5 per cent of the parties in category $1 ; 24.7$ per cent in category $2 ; 19.2$ per cent in category 3 . See CoP17 Doc. 22 (2016), p 3, para 8, Annex 3; and SC67 Doc. 11, para 7, <https://cites.org/sites/ default/files/eng/com/sc/67/E-SC67-11.pdf>.

76. Peter H Sand, 'Institution-Building to Assist Compliance with International Environmental Law: Perspectives' (1996) 56 Heidelberg Journal of International Law 774-95; and JE Baker, 'A Substantive Theory of the Relative Efficiency of Environmental Compliance Strategies: The Case of CITES' (1999) 2 Journal of International Wildlife Law and Policy 1-45.

77. Through field missions and long-distance training programmes for professional staff (CITES Virtual College, <https://cites:unia.es>); see CoP17 Doc. 15 (2016).

78. Instrument for the Establishment of the Restructured Global Environment Facility, adopted at Geneva on 14 March 1994, 33 ILM 33 1283; see the report by the CITES Secretariat on 'Access to Finance, including GEF Funding', CoP17 Doc. 7.5 (2016), and generally Justin Wolst, 'History and Principles of Funding of International Environmental Law' in Shawkat Alam et al (eds), Routledge Handbook of International Environmental Law (Routledge, London 2013) $156-74$ at $160-1$.

79. See Sand (n 73) 254-60. On the concept of retorsion (as distinct from reprisals) see generally Oscar Schachter, 'International Law in Theory and Practice' (1982) 178 Hague Academy of International Law: Collected Courses 9-396 at 168; Lori F Damrosch, 'Enforcing International Law through Non-forcible Measures' (1997) 269 Hague Academy of International Law: Collected Courses 9-250 at 54; Math Noortmann, Enforcing International Law: From Self-help to Self-contained Regimes (Ashgate, Aldershot 2005) 42-5; and Thomas Giegerich, 'Retorsion' in Max Planck Encyclopedia of Public International Law (Vol 8, OUP, Oxford 2012) 976-81.

80. Reprinted in 46 ILM 1174, with an introductory note by C Payne. 
special reporting or a compliance action plan, and recommend other measures (paragraph 29); and

(c) where the matter remains unresolved, the Standing Committee may as a last resort recommend an embargo; ie, 'the suspension of commercial or all trade in specimens of one or more CITES-listed species' with the Party concerned (paragraph 30).

While a suspension may thus focus on trade in particular species only ('species-specific'), the most effective sanctions of course are general embargoes ('country-specific'); ie, denying recognition to all CITES export permits issued by the targeted country as valid documentation for entry anywhere else in the world. As a result, the country is excluded from access to the lucrative legal export markets for some 35,000 species of commercially tradable wildlife and wildlife products listed in Appendix II of the Convention. In view of the economic stakes involved, therefore, the mere threat of an embargo often tends to produce near-instant compliance. ${ }^{81}$ Over the past 30 years, general (country-specific) CITES embargoes have been imposed in more than a hundred cases, in the form of collective trade suspensions targeting 60 countries at one time or another (some more than once), as shown in Table 1. The reasons cited for these trade sanctions by the Conference or the Standing Committee varied, and gradually expanded over time - from persistent general compliance issues (since 1985), ${ }^{82}$ to inadequate legislation (since 1997/1999), ${ }^{83}$ inadequate reporting (since 2000/ 2002), ${ }^{84}$ and inadequate controls of ivory trade (since 2004/2008). ${ }^{85}$

The extraordinary effectiveness of the scheme is demonstrated by the fact that in more than 80 per cent of the cases, trade suspensions could be lifted within less than a year, on the basis of evidence that the targeted country had returned to compliance (by enacting or amending the necessary legislation, submitting overdue reports, or complying with action plan requirements). ${ }^{86}$ A comparative United Nations University study on trade impacts of multilateral environmental agreements credits CITES embargoes with 'an almost 100 per cent success rate'. ${ }^{87}$ Even in cases where recommended trade bans were not implemented by all Member States ${ }^{88}$ denial of market access in a few key countries usually proved sufficient to induce compliance.

81. See Peter H Sand, 'Sanctions in Case of Non-Compliance and State Responsibility: Pacta sunt servanda - Or Else?' in Durwood Zaelke et al (eds), Making Law Work: Environmental Compliance and Sustainable Development (vol 1, Cameron May, London 2005) 259-71.

82. See Resolution Conf. 5.2 (1985: 'Implementation of the Convention in Bolivia'); Reeve (n 71) 97-9.

83. Above (n 74); Reeve (n 71) 136-47.

84. Resolution Conf. 11.17 (Rev. CoP17) and Decision 11.37 (2000); Summary Record of the 66th session of the Standing Committee, Doc. SC66 SR (2016), p 28; and Reeve (n 71) 147-52. 85. Decision 13.26 (Rev. CoP15/2010), Annex 2, para 5 ("the Conference of the Parties recommends that Parties not authorize commercial trade in specimens of CITES-listed species with the State in question'); Wijnstekers (n 20) 627.

86. For case-by-case assessments, see Reeve (n 71) 91-188; and Rosalind Reeve, 'Wildlife Trade, Sanctions and Compliance' (2006) 82 International Affairs 881-97 at 892-5.

87. Duncan Brack, 'Environmental Treaties and Trade: Multilateral Environmental Agreements and the Multilateral Trading System' in GP Sampson and WB Chambers (eds), Trade, Environment and the Millennium (2nd edn, United Nations University Press, Tokyo 2002) 321-52 at 334; see also Kal Raustiala, Reporting and Review Institutions in 10 Multilateral Environmental Agreements (UNEP, Nairobi 2001) 27 (CITES embargos as 'a unique and potent tool in MEA management'). 88. Eg, Austria, Switzerland and the United States did not implement a 1992 CITES embargo against Italy. 
Table 1 CITES trade embargoes, 1985-2016

\begin{tabular}{|c|c|c|c|c|}
\hline \multirow[t]{2}{*}{ States targeted } & \multicolumn{4}{|c|}{ Reasons for trade suspension } \\
\hline & $\begin{array}{l}\text { (a) General } \\
\text { compliance } \\
\text { issues }\end{array}$ & $\begin{array}{l}\text { (b) Inadequate } \\
\text { legislation }\end{array}$ & $\begin{array}{l}\text { (c) Inadequate } \\
\text { reporting }\end{array}$ & $\begin{array}{l}\text { (d) Inadequate ivory } \\
\text { controls }\end{array}$ \\
\hline Bolivia & 1985-87 & & & \\
\hline Un. Arab Emirates & $\begin{array}{l}\text { 1985-90, } \\
2001-02\end{array}$ & & & \\
\hline El Salvador & $1986-87$ & & & \\
\hline Equatorial Guinea & 1988-92 & 2004 & & \\
\hline Grenada & 1991-92 & & $2016-$ & \\
\hline Thailand & 1991-92 & & & \\
\hline Italy & 1992-95 & & & \\
\hline China and Taiwan & 1993-98 & & & \\
\hline Greece & 1998-99 & & & \\
\hline Guyana & & 1999 & & \\
\hline Senegal & & 1999-2000 & & \\
\hline Afghanistan & 1999 & & $2002-03,2013-$ & \\
\hline Rwanda & 1999 & 2004-10, 2012 & 2002-03, 2016- & 2008 \\
\hline Dem. Rep. Congo & $2000-01$ & & & 2008,2015 \\
\hline Yemen & & 2002 & & \\
\hline Vietnam & & 2002 & & \\
\hline Fiji & & $2002-03$ & & \\
\hline Dominica & & & 2002-03, 2008 & \\
\hline Vanuatu & & & 2002-03, 2016- & \\
\hline Liberia & & 2004-08, 2016- & $2002-05$ & \\
\hline Somalia & & $2004-$ & $\begin{array}{l}2002-03,2006- \\
16\end{array}$ & $2008-12$ \\
\hline Djibouti & & 2004 & $\begin{array}{l}2002,2008, \\
2013\end{array}$ & \\
\hline Mauritania & & 2004 & $2003-10$ & \\
\hline Mozambique & & 2004 & & \\
\hline Sierra Leone & & 2004 & 2011 & \\
\hline Gambia & & 2004-05 & 2014 & \\
\hline India & & 2004-05 & & \\
\hline Algeria & & 2004 & 2004-05 & \\
\hline Guinea-Bissau & & 2004-08, 2016- & 2004-06, 2012 & \\
\hline Panama & & 2004 & $2016-$ & \\
\hline Central Afric. Rep. & & 2004 & $2016-$ & \\
\hline Nigeria & 2005-08 & 2012 & & $2008,2015-16$ \\
\hline Uganda & & & 2006 & \\
\hline Comoros & & 2012 & $\begin{array}{l}2006,2010 \\
2014\end{array}$ & \\
\hline S.Tomé \& Principe & & & 2006, 2016 & \\
\hline Mongolia & & & 2006, 2016- & \\
\hline Ethiopia & & & & 2008 \\
\hline Chad & & & & 2008 \\
\hline Sri Lanka & & & & 2008 \\
\hline Sudan & & & & 2008 \\
\hline Swaziland & & & & 2008 \\
\hline Nepal & & & 2008,2012 & 2008 \\
\hline
\end{tabular}

(continued) 
Table 1 CITES trade embargoes, 1985-2016 (Continued)

\begin{tabular}{|c|c|c|c|c|}
\hline \multirow[t]{2}{*}{ States targeted } & \multicolumn{4}{|c|}{ Reasons for trade suspension } \\
\hline & $\begin{array}{l}\text { (a) General } \\
\text { compliance } \\
\text { issues }\end{array}$ & $\begin{array}{l}\text { (b) Inadequate } \\
\text { legislation }\end{array}$ & $\begin{array}{l}\text { (c) Inadequate } \\
\text { reporting }\end{array}$ & $\begin{array}{l}\text { (d) Inadequate ivory } \\
\text { controls }\end{array}$ \\
\hline Gabon & & & & $2008-12$ \\
\hline Guinea & $2013-$ & & 2016- & 2008 \\
\hline Lesotho & & & $2008,2013-$ & \\
\hline Cape Verde & & & 2010 & \\
\hline Samoa & & 2012 & 2010 & \\
\hline Libya & & & 2011 & \\
\hline Congo & & & 2011, 2016- & \\
\hline Paraguay & & 2012 & & \\
\hline Syria & & & 2012 & \\
\hline Solomon Islands & & & 2012,2016 & \\
\hline Laos & & & 2014 & 2015,2016 \\
\hline Malawi & & & 2014 & \\
\hline St.Vincent \& Gren. & & & 2014 & \\
\hline Angola & & & & 2016 \\
\hline Venezuela & 2016 & & & \\
\hline Bhutan & & & $2016-$ & \\
\hline Mali & & & $2016-$ & \\
\hline Nicaragua & & & $2016-$ & \\
\hline
\end{tabular}

The formal legal basis for these trade suspensions is Article XIV(1)(a) of the Convention, which expressly reserves the right of States to take 'stricter domestic measures regarding the conditions for trade, taking, possession of transport of specimens of species included in appendices I,II and III, or the complete prohibition thereof' (emphasis added). Implicitly, therefore, the Article also authorizes the use of unilateral or multilateral economic sanctions by way of trade bans against other States, provided such measures are compatible with applicable general rules of international law. ${ }^{89}$ Embargoes have not only been imposed on parties to the Convention, but also on nonparty States failing to comply with 'comparable' documentation standards under Article $\mathrm{X}$ ('trade with States not party to the Convention'). ${ }^{90}$

Surprisingly perhaps, CITES practice in this field seems to have gone virtually unnoticed in most of the general literature of international law. In their seminal 1995 study on

89. For a comparison of the CITES compliance procedures with the UN International Law Commission's criteria for the lawful exercise of collective countermeasures, see Sand (n 81) 269-71.

90. See Resolution Conf. 9.5 (Rev. CoP15, 1994/2010). Given that third-party States are not bound by CITES rules, conduct giving rise to sanctions/countermeasures in these cases (ie, persistent refusal to furnish documentation required pursuant to Art X) cannot be characterized as a breach of the Convention, but as a simple 'unfriendly act'. On compatibility with GATT/WTO law, see Arun Goyal, The WTO and International Environmental Law: Towards Conciliation (OUP, Oxford 2006) 84-5; but see the skeptical comments by Christian Tomuschat, 'Obligations Arising for States Without or Against Their Will' (1993) 241 Hague Academy of International Law: Collected Courses 195-374 at 271; and Malgosia Fitzmaurice, 'Environmental Compliance Control' in Max Planck Encyclopedia of Public International Law (Vol 3, OUP, Oxford 2012) 541-61 at 554-5 ('controversial'). 
The New Sovereignty, Abram and Antonia Chayes claimed that 'sanctioning authority is rarely granted by treaty, rarely used when granted, and likely to be ineffective when used'; 91 and in 2001 the UN International Law Commission concluded that 'such cases are controversial and the practice is embryonic'. ${ }^{92}$ At the ripe age of 30, the CITES embargo certainly is a portly embryo. And even though there were initial concerns over potential conflicts with the world trade regime, ${ }^{93}$ multilateral CITES trade suspensions are now generally considered compatible with GATT Article XX, ${ }^{44}$ and their legality has never formally been contested in the World Trade Organization (WTO).$^{95}$

\section{OUTLOOK: THE CHALLENGE OF LEGITIMACY}

Quite apart, however, from the normative legality and the practical effectiveness of the CITES compliance procedures, the question remains whether this unique system also meets other criteria which an international regulatory regime must take into account if it expects to remain accepted and sustainable in the long run. It has indeed been pointed out that "the viability of the "regulatory phenomenon" is linked to a

91. Abram and Antonia Chayes, The New Sovereignty: Compliance with International Regulatory Agreements (Harvard University Press, Cambridge MA 1995) 32-3.

92. Commentary on Pt Three, Ch II (Countermeasures) of the 'Draft Articles on State Responsibility', Report of the International Law Commission: 53rd Session, UN-Doc. A/56/ 10 (2001), p 327 (para 8), and commentary on Art 54 (Measures taken by States other than an Injured State), p 351 (para 3: 'practice on this subject is limited and rather embryonic'); James Crawford, The International Law Commission's Articles on State Responsibility: Introduction, Text and Commentaries (CUP, Cambridge 2002) 283.

93. Eg, J Cameron and J Robinson, 'The Uses of Trade Provisions in International Environmental Agreements and Their Compatibility with the GATT' (1991) 2 Yearbook of International Environmental Law 3-30 at 8-12; Steve Charnovitz, 'Green Roots, Bad Pruning: GATT Rules and Their Application to Environmental Trade Measures' (1994) 7 Tulane Environmental Law Journal 299-352 at 333; and Christine Crawford, 'Conflicts between the Convention on International Trade in Endangered Species and the GATT in Light of Actions to Halt the Rhinoceros and Tiger Trade' (1995) 7 Georgetown International Environmental Law Review 555-85.

94. General Agreement on Tariffs and Trade, 1867 UNTS 187. On consultations with the GATT Secretariat during the preparatory negotiations for CITES in 1971, see Chris Wold, 'The Convention on International Trade in Endangered Species of Wild Fauna and Flora' in Robert Housman et al (eds), The Use of Trade Measures in Select Multilateral Environmental Agreements (UNEP, Geneva 1995) 165; and RG Tarasofsky, 'Ensuring Compatibility between Multilateral Environmental Agreements and GATT/WTO' (1996) 7 Yearbook of International Environmental Law 52-74.

95. See the joint statement by the CITES and WTO Secretariats, CITES and the WTO: Enhancing Cooperation for Sustainable Development (Geneva 2015) 5 ('in fact, there has not been any WTO dispute directly challenging a CITES trade measure'). See also Marcel Yeater and JC Vasquez, 'Demystifying the Relationship between CITES and the WTO' (2001) 10 Review of European Community and International Environmental Law 271-6; Chris Wold et al (eds), Trade and the Environment: Law and Policy (2nd edn, Carolina Academic Press, Durham NC 2011) 646-7; Ulrich Beyerlin and Thilo Marauhn, International Environmental Law (Hart Publishing, Oxford 2011) 434 ('there seems to be tacit approval of the WTO compatibility of CITES measures'). 
major challenge: that of its legitimacy'. ${ }^{96}$ Legitimacy in this context may be defined in procedural terms of fairness, ${ }^{97}$ and in empirical/sociological terms of equitable outcomes. ${ }^{98}$

Yet, the statistical evidence of CITES trade sanctions over the past three decades reveals a rather perplexing North-South imbalance. As Table 1 shows, no less than 95 per cent of the States targeted by all-out trade embargoes were developing countries. ${ }^{99}$ Even though inadequate implementation of the Convention is undoubtedly often caused by a lack of administrative and financial capacities in the Third World, ${ }^{100}$ to find sanctionable compliance deficits almost exclusively in the South comes as something of an empirical surprise. Critics have not hesitated to attribute these findings to a hidden neocolonial bias of the regime. ${ }^{101}$ Past 'infraction reports' by the CITES Secretariat and by

96. Laurence Boisson de Chazournes, 'Gouvernance et régulation au 21ème siècle: quelques propos iconoclastes', in Laurence Boisson de Chazournes and Rostane Mehdi (eds), Une société internationale en mutation: quels acteurs pour une nouvelle génération? (Bruylant, Brussels 2005) 19-40 at 40 ('la viabilité du phénomène "régulatoire" est liée à un défi majeur: celui de sa légitimité'); and Daniel Bodansky, 'The Legitimacy of International Governance: A Coming Challenge for International Environmental Law' (1999) 93 American Journal of International Law 596-624.

97. See Steinar Andresen and Ellen Hey, 'The Effectiveness and Legitimacy of International Environmental Institutions' (2005) 5 International Environmental Agreements: Politics, Law and Economics 211-26; Steven Bernstein, 'Legitimacy in Global Environmental Governance' (2005) 1 Journal of International Law and International Relations 139-66 at 156-62; and generally Thomas M Franck, Fairness in International Law and Institutions (Clarendon Press, Oxford 1995) 22-6; Günther Handl, 'International "Lawmaking" by Conferences of the Parties and Other Politically Mandated Bodies', in Wolfrum and Röben (n 52) 127-43 at 140 ('normative effectiveness as a function of legitimacy of process'); Daniel C Esty, 'Good Governance at the Supranational Scale: Global Administrative Law' (2006) 115 Yale Law Journal 1490-562 at 1521-3 ('procedural legitimacy'); Inger J Sand, 'Legitimacy in Global and International Law: A Sociological Critique' in Chris Thornhill and Samantha Ashenden (eds), Legality and Legitimacy: Normative and Sociological Approaches (Nomos, Baden-Baden 2010) 147-69 at 163-7; Jutta Brunnée and Stephen J Toope, Legitimacy and Legality in International Law: An Interactional Account (CUP, Cambridge 2010); Daniel Bodansky, 'Legitimacy in International Law and International Relations' in Jeffrey L Dunoff and Mark A Pollack (eds), Interdisciplinary Perspectives on International Law and International Relations: The State of the Art (CUP, Cambridge 2012) 321-42.

98. Daniel Bodansky, 'Legitimacy' in Bodansky et al (n 41) 704-23, at 709; Staal (n 50) 40. 99. 58 of the total number of 60 States targeted, 28 of them more than once. By comparison, the share of developing countries in the overall CITES membership (currently 182 States) is less than 70 per cent.

100. Above n 76; see also AH Chayes et al, 'Active Compliance Management in Environmental Treaties' in Winfried Lang (ed), Sustainable Development and International Law (Graham and Trotman, London 1995) 75-89 at 80; and Jutta Brunnée, 'Enforcement Mechanisms in International Law and International Environmental Law' in Ulrich Beyerlin et al (eds), Ensuring Compliance with Multilateral Environmental Agreements: A Dialogue between Practitioners and Academia (Nijhoff, Leiden 2006) 1-23 at 19 ('non-complying parties are most likely to be States with genuine capacity limitations').

101. Maaria Curlier and Steinar Andresen, 'International Trade in Endangered Species: The CITES Regime' in Edward L Miles et al (eds), Environmental Regime Effectiveness: Confronting Theory with Evidence (MIT Press, Cambridge MA 2002) 357-78 at 368 ('the North imposed its will'); Charlotte Epstein, 'The Making of Global Environmental Norms: Endangered Species Protection' (2006) 6 Global Environmental Politics 32-52 at 50 ('CITES as a neo-colonial imposition'); Dilys Roe, 'Blanket Bans: Conservation or Imperialism?', (2006) 
non-governmental organization (NGO) observer groups certainly indicate that infringements of treaty rules and Conference resolutions are in no way the sole prerogative of wildlife-exporting countries; ${ }^{102}$ so there must be other explanations for the skewed geographical distribution of trade embargoes as currently practised.

To illustrate my point, let me conclude with a recent case from the Pacific region that is well documented and anything but trivial. From 2001 to 2016, the Japanese Institute of Cetacean Research (ICR, Nihon Geirui-Kenkyūjo) has caught a total of 1,369 sei whales from areas outside Japanese territorial jurisdiction in the North Pacific, as part of the Government's 'Research Plan for Cetacean Studies in the Western North Pacific Under Special Permit' (JARPN-II) ${ }^{103}$ Yet, the North Pacific population of sei whales (Balaenoptera borealis) has been listed as strictly protected under Appendix I of CITES ever since the entry into force of the Convention in 1976. Although Japan together with Norway - had entered a reservation under Article XV(3) against the Appendix-I-listing of the entire species after CoP3 (New Delhi 1981), that reservation explicitly does not apply to the North Pacific population, which therefore remains categorically excluded from international trade or introduction from the sea under Article III. ${ }^{104}$ Consequently, the Japanese catch and introduction of North Pacific sei whales raises a question of persistent non-compliance, and possibly an invocation of Article XIII and Resolution Conf. 14.3, for several reasons:

- To date, the Japanese government has not designated an independent national scientific authority under Article IX(1)(b), qualified to issue 'non-detriment findings' for introduction from the sea under Article III(5)(a). ${ }^{105}$ Resolution Conf. 10.3 (1997) expressly requires scientific authorities to be 'independent of management authorities'. Yet the 'Resources and Environment Research Division' in Tokyo, which the Government notified to the CITES Secretariat as its national 'scientific authority for cetaceans', is a mere administrative sub-division under orders from the Japanese Fisheries Agency (JFA), which serves as the designated 'management authority for whales'. ${ }^{106}$ The country

40 Oryx 1-3; Bowman (n 19) 236; and Rosaleen Duffy, 'Global Environmental Governance and North-South Dynamics: The Case of CITES' (2013) 31 Environment and Planning (C): Government and Policy 222-39.

102. Eg, see the list of serious German compliance gaps, Proceedings of the Third Meeting of the Conference of the Parties (New Delhi 1981), vol I, 297-302 and 411-14; J Burton, 'Comments on the Annual Report by the Federal Republic of Germany on its Implementation of CITES' (1981) 3:3/4 TRAFFIC Bulletin 36-40; and Sand (n 20) 177.

103. Text in International Whaling Commission (IWC) Scientific Committee Paper SC/54/O2 (2002); see Peter H Sand, "Scientific Whaling": Whither Sanctions for Non-Compliance with International Law?' (2008) 19 Finnish Yearbook of International Law 93-124.

104. Current list of reservations (as of 21 November 2016) available at <http://cites.org/eng/ app/reserve.php>; see Mari Koyano, 'Whaling Issues: International Law and Japan' (2013) 63 Hokkaido Law Review 201-42 at 239. By contrast, Iceland entered a valid reservation against the Appendix-I-listing of all sei whales (including the North Pacific population) at the time of its accession to the Convention on 2 April 2004.

105. So-called 'IFS Certificates' for introduction from the sea of Appendix-I-specimens 'taken in the marine environment not under the jurisdiction of any State'; see Resolution Conf. 14.6 (Rev. CoP16, 2007/2014), Annex I, paras 1-3, and Secretariat Report CoP17 Doc. 36 (2016). 106. At the same postal address. Yet Japan's most recent biennial national report (for the years 2013-2014) brazenly states that the scientific authority is 'independent from the Management Authority'; Report No 01/12/15e, S. 8 (D2), available at <http://cites.org/sites/default/files/ reports/13-14Japan_0.pdf>. 
therefore has for years been in manifest non-compliance with one of the elementary treaty obligations listed as a potential basis for trade sanctions. ${ }^{107}$ Even so, Japan continues to be listed since 1997 in category 1 ('meeting all requirements') of the Secretariat's 'National Legislation List', 108 critical comments in the literature notwithstanding. ${ }^{109}$

- The 'special permits' issued since 2001 by the JFA for the taking of North Pacific sei whales for research purposes pursuant to Article VIII of the International Whaling Convention ${ }^{110}$ do not meet the stipulations of CITES Article III(5) for

107. Above (n 74). Failure to designate an independent scientific authority was among the reasons for trade embargoes against Afghanistan and Rwanda in 1999; see CITES Notification to the Parties No 1999/24 of 12 March 1999; Reeve (n 71) 152-4.

108. Above ( $\mathrm{n} 75$ ). An initial expert analysis commissioned by the Secretariat in 1994 (TRAFFICWWF USA, Washington DC) had ranked Japan in category 2 only ('legislation believed not to meet all the requirements for the implementation of CITES'), CoP9 Doc. 9.24/Rev., Annex 1 (1994); see Baker (n 76) 33. As from 1 May 1997, the Secretariat changed the ranking to category 1, apparently on the basis of legislative changes unilaterally reported by the Japanese Management Authority; CoP10 Doc. 10.31/Rev., Annex 1 (1997). Since then, the country has been ranked in category 1 in all subsequent lists; see CoP16 Doc. 28, Annex 2/Rev. 1 (2013). Japan in turn is among the important sponsors (US\$50,000 annually) for the National Legislation Project of the Secretariat; see CITES External Trust Fund (QTL): Status of Contributions as of 31 December 2015, CoP17 Doc. 7.3, Annex 7, Activity D-1 (2016).

109. See PA Mofson, 'Protecting Wildlife from Trade: Japan's Involvement in the Convention on International Trade in Endangered Species' (1994) 3 Journal of Environment and Development 91-107 at 96; K Ishibashi, 'The Effectiveness of Mechanisms for Supervision or Compliance Control of Multilateral Environmental Agreements: A Critical Study of Compliance with CITES' [in Japanese] (1995) 15 Kagawa Hōgaku 53-128; M Taguchi, International Regimes and Cooperation: An Analysis of the Convention on International Trade in Endangered Species of Wild Fauna and Flora and Japan (University of Oregon thesis, Portland, OR 1996); H Kato, 'Implementation of Multilateral Environmental Agreements in Japan Through Domestic Environmental Legislation' (2000) 43 Japanese Annual of International Law 117-49 at 135-42; JV Feinemann and K Fujikura, 'Japan: Consensus-Based Compliance' in EB Weiss and HK Jacobson (eds), Engaging Countries: Strengthening Compliance with International Environmental Accords (MIT Press, Cambridge MA 2000) 253-90 at 269-73; M Sakamoto, Black and Grey: Illegal Ivory in Japanese Markets (2nd edn, Japan Wildlife Conservation Society, Tokyo 2004). On 28 February 2017, a bill amending Japan's Endangered Species Conservation Act was approved by Cabinet, but conservationists keep criticizing the modifications as a 'toothless revamp'; see D Kikuchi, Japan Times (Tokyo, 16 January 2017).

110. Above (n 35). The special permit issued to the ICR on 9 May 2016 (No 28-SUIKA-155) by the Japanese Ministry of Agriculture, Forests and Fisheries, for the introduction of 90 sei whales and 25 Bryde's whales from the Northwest Pacific for research purposes, has been publicized on 13 May 2016 by the International Whaling Commission as an annex to the Circular Communication to Commissioners and Contracting Governments IWC.CCG.1205, available at $<$ https://iwc.int/home>, Circulars, IWC Archive no 5835. An IWC Expert Panel for Evaluation of Japan's Whaling Program in the Northwest Pacific (Tokyo, February 2016) expressed doubts about the 'scientific' usefulness of the programme ('the results have not led to improved conservation and management of cetaceans or other marine living resources or the ecosystem'); IWC-Doc. SC/66b/Rep06, IWC Archive no 5824, p 48, available at $<$ https://archive.iwc.int/ pages/view/php?ref=5824\&k=>. Yet, the subsequent report of the IWC Scientific Committee (San Diego, May-June 2016, chaired by Japan) merely concluded: 'The Committee was unable to reach consensus on whether the additional information was sufficient to justify the revised number of whales to be taken under the JARPN-II programme'; Report of the Scientific Committee, (Supplement 2016) 17 Journal of Cetacean Research and Management 80. 
introduction from the sea of specimens of a species listed in Appendix I. Those provisions require, in addition to the mandatory independent scientific 'nondetriment' certificate, a finding by the competent Management Authority that 'the specimen is not to be used for primarily commercial purposes'. Resolution Conf. 5.10 (Rev. CoP15) specified that requirement as follows: "[A]ll uses whose non-commercial aspects do not clearly predominate shall be considered to be primarily commercial in nature, with the result that the import of specimens of Appendix-I species should not be permitted'. ${ }^{111}$ In view of the 'factory ship' practice of the ICR, ${ }^{112}$ which only extracts less than one per cent of a whale's biomass for subsequent scientific analysis (biopsy and stomach content samples), while the economically usable rest of the catch is processed on board as 'by-products' for subsequent marketing, ${ }^{113}$ that definition would seem to leave hardly any room for discretionary interpretation. The continuation of the lethal ICR practice for 'research purposes', as announced by the JFA, ${ }^{114}$

111. Definition of 'primarily commercial purposes' (1985/2014), available at <https://cites.org/ eng/res/05/05-10R15.php $>$, general principle 3. According to the second sentence of the principle, the burden of proof is on the applicant, in this case on the Institute of Cetacean Research (ICR). See also Resolutions Conf. 12.3 (Rev. CoP16, 2002/2014) and Conf. 14.6 (Rev. CoP16, 2007/2014). Earlier special permits by the JFA expressly relied on CITES Art XIV(5), which however applies to specimens of species listed on Appendix II only, hence not to North Pacific sei whales; see (n 104) above.

112. The ICR factory ship operating in the North Pacific (the Nisshin-Maru, owned by the KyōdōSenpaku Ltd. shipping agency) is the same vessel that operated for many years in the Antarctic Southern Ocean; see the ICJ judgment of 31 March 2014 on Whaling in the Antarctic (Australia v Japan, New Zealand intervening), ICJ Reports 2014, 295 (para 232). On the aftermath of the judgment see JJ Smith, 'Evolving to Conservation? The International Court's Decision in the Australia v Japan Whaling Case' (2014) 45 Ocean Development and International Law 301-27; A Telesetsky, DK Anton and T Koivurova, 'The International Court's Decision in Australia v Japan: Giving Up the Spear or Refining the Scientific Design?' (2014) 45 Ocean Development and International Law 328-40; PJ Clapham, 'Japan's Whaling Following the International Court of Justice's Ruling: Brave New World - Or Business as Usual?' (2015) 51 Marine Policy 238-41; M Fitzmaurice and D Tamada (eds), Whaling in the Antarctic: Significance and Implications of the ICJ Judgment (Brill Nijhoff, Leiden 2016); and the symposium on 'Whaling in the Antarctic' (E Cannizzaro ed), (2017) 27 European Journal of International Law 1025-69.

113. Approximately 40 per cent of biomass is usually discharged on the spot as waste, ie thrown overboard at sea. Commercial sales of the usable rest 'by-products' in Japan account for over 85 per cent of the ICR's revenues; see Sand (n 103) 109. On market allocation and price-setting by the ICR 'Sales Council', see A Endo and M Yamao, 'Policies Governing the Distribution of By-Products from Scientific and Small-Scale Coastal Whaling in Japan' (2007) 31 Marine Policy 169-81. Sei whale meat from Japanese 'scientific whaling' in the North Pacific has also turned up in illegally exported products in South Korea and California, according to DNA tests carried out in 2009; see S Baker et al, 'Genetic Evidence of Illegal Trade in Protected Whales Links Japan with the US and South Korea' (2010) 6 Biology Letters: London Royal Society 647-50.

114. On 8 November 2016, the JFA submitted a 'New Research Plan for the North Pacific' to the IWC, which increases the annual catch quota of sei whales from 90 to 140 specimens from 2017 onwards, with the declared objective of data collection for the future resumption of commercial whaling; see Circular Communication IWC.ALL.270, file no NEWREP_NP_final_161108. On 2 December 2016, 15 Japanese environmental NGOs jointly called on the Government to revoke the new plan, drawing attention to its violation of CITES; see <http://ika-net.jp/en/our-actions/ whaling-issue/333-jntstmnt-no-newrep-np2016e>. On 18 January 2017, the Government of the Netherlands on behalf of the EU Member States expressed concern over the proposed increase 
appears all the less plausible in light of the fact that simultaneously with the 2016 North Pacific hunt yet another ICR vessel was at sea in the very same ocean region in order to collect scientific data (inter alia on sei whales) by 'non-lethal' methods, as part of an ongoing monitoring project under the auspices of the International Whaling Commission. ${ }^{115}$

Yet, part of the political-empirical reality is the fact that Japan has not only been a member of the CITES Standing Committee (chaired by Norway) for the past ten years, ${ }^{116}$ but also the second-largest contributor - after the United States - to the Convention's budget. ${ }^{117}$ For diplomatic reasons, other Member States will inevitably think twice before antagonizing such a heavy-weight member country by allegations of non-compliance - let alone initiating formal dispute resolution proceedings for (in-)application of treaty provisions (which in any event could only be brought, under Article XVIII, 'by mutual consent'). ${ }^{118}$ Moreover, future recourse to the International Court of Justice is precluded,

in sei whale catches, as 'conflicting with Japan's CITES obligations'; Circular Communication IWC.CCG.1250. The Japanese Government's response of 15 March 2017 states, without further explanation, that 'Japan ensures its compliance with relevant provisions of CITES at all occasions including 'Introduction from the Sea' of sei whales in implementing NEWREP-NP'; Circular Communication IWC.CCG.1256. Resolution 6.055 of the 25th World Conservation Congress of the International Union for Conservation (IUCN, held in Hawaii in September 2016) had also called for termination of the North Pacific programme, adding that the special permits issued in May 2016 (above n 110) contravened IWC Resolution 2014-5 of 31 March 2014. In May 2017, the IWC Scientific Committee reviewed Japan's NEWREP-NP and endorsed the recommendations of an independent expert panel (Tokyo, February 2017), to the effect that 'lethal sampling' of North Pacific sei whales was 'currently unjustified and should be halted until more research has been conducted'; IWC/67/Rep01 (6 June 2017) 109, and Annex P3 at 18. Yet, on 12 June 2017 Japan issued new special permits for 134 sei whales to be taken offshore in the North Pacific from June to September 2017; see Circular Communication IWC.CCG.1264 (15 June 2017), and PJ Clapham et al., 'Whaling Permits: Japan Disregards Whaling Review Again' (6 July 2017) 546:7661 Nature 32.

115. IWC/Japan Joint Cetacean Sighting Survey Cruise in the North Pacific (POWER), from 2 July to 30 August 2016; ICR Press Release of 1 July 2016, available at <http://www.icrwhale. org/160701ReleaseENG.html>. The objective of the project is the collection of data on the populations of sei whales, fin whales and Bryde's wales in the North Pacific by photo identification and non-lethal biopsies, with the help of so-called Larsen air guns; on this technique see the expert testimony (in the IWC Antarctic Whaling case, $\mathrm{n} \mathrm{112}$ ) by $\mathrm{N}$ Gales, available at $<$ http://www.icj-cij.org/docket/files/148/17422.pdf>.

116. At the 17th Conference meeting in October 2016, the composition of the Standing Committee changed, with China succeeding Japan as full member for the Asian region and Japan becoming the alternate member.

117. According to the contribution scale for 2016 (US\$647,393), see CITES Trust Fund (CTL): Status of Contributions as of 30 June 2016, CoP17 Doc. 7.3, Annex 10, Tab. 1 (2016); plus voluntary contributions (extra-budgetary funding, QTL) for 2013-2015 in the amount of US\$220,994, and contributions to special projects such as the joint tropical timber programme of CITES with the International Tropical Timber Organization (ITTO) in Yokohama; see CoP17 Doc. 7.5, p 6, Tab. 1 (2016).

118. The dispute settlement clause of CITES Article XVIII is a notorious 'paper tiger', which like similar clauses in other multilateral environmental agreements - has never been used in 40 years of treaty practice; see CPR Romano, The Peaceful Settlement of International Environmental Disputes: A Pragmatic Approach (Kluwer Law International, The Hague 2000) 44; and Sand, 'Environmental Dispute Settlement and the Experience of the UN Compensation Commission' (2011) 54 Japanese Yearbook of International Law 151-89 at 157. 
following Japan's amendment of its acceptance of the court's compulsory jurisdiction on 6 October 2015 (in the wake of the Antarctic Whaling judgment), which now expressly excludes 'any dispute arising out of, concerning, or relating to research on, or conservation, management or exploitation of, living resources of the sea' ${ }^{119}$

When the UK CITES management authority in 2007 for the first time had the audacity to draw the attention of the Secretariat in Geneva to possible Japanese treaty infractions with regard to trade in whale meat of Appendix-I specimens, and to suggest non-compliance measures under Article XIII, the Secretariat's mild response was that the granting of special permits for 'research whaling' under Article III(5) was entirely within the discretion of the national management authority concerned. ${ }^{120}$ Whereupon the legal adviser of the ICR (who from 2005 to 2008 also served as a member of the Japanese delegation in the CITES Standing Committee) promptly declared both the Antarctic and the North Pacific whaling programmes compatible with the Convention, citing the Secretariat's opinion in support. ${ }^{121}$ Over the next six years, further appeals to the CITES Secretariat for action regarding North Pacific sei whale catches were unsuccessful; ${ }^{122}$ in September 2016, however, the Secretariat reported to the Standing Committee that Article XIII proceedings have now been initiated against Japan. ${ }^{123}$

The legitimacy of an international nature conservation regime is crucially dependent on trust $1^{124}$ - trust that rules will be applied equally to all contracting parties, and ipso iure to all non-compliant parties - on a common basis of transparency and accountability. ${ }^{125}$ CITES, and its unique compliance procedure in particular, is widely respected for its performance in protecting endangered species against the threats of illegal trade and overexploitation. Even so, when an otherwise successful treaty regime begins to apply - for subtle diplomatic reasons - double standards in favour of prominent Member States, ${ }^{126}$ the regime as a whole could risk losing part of its credibility, and hence its sociological balance and legal certitude.

119. Text of the amendment in UN Treaty Database: Status of Treaties, ch I/4, declaration no 42, available at $<$ https://treaties.un.org/pages/ViewDetails.aspx $?$ src=IND\&mtdsg_no=I$4 \&$ chapter=1\&lang=en\#EndDec $>$. Japan's original acceptance (the jurisdictional basis of the ICJ's 2014 Antarctic Whaling judgment, n 112) did not contain such an exclusion.

120. Email correspondence between T Salmon (UK Department for Environment, Food and Rural Affairs) and Willem Wijnstekers (CITES Secretary General), on 7 November 2007 ('re: commercial sale of whale meat'); on file with the author.

121. Dan Goodman, 'Japan's Research Whaling Is Not Unlawful and Does Not Violate CITES Trade Rules', (2010) 13 Journal of International Wildlife Law and Policy 176-82 at 181-2; contra Vasili Papastavrou and Patrick Ramage, 'Commercial Whaling by Another Name? The Illegality of Japan's Scientific Whaling: Response to Dan Goodman' (2010) 13 Journal of International Wildlife Law and Policy 183-7.

122. Eg, see the email response from the CITES Legal Affairs Unit to the author (3 September 2012): 'We have concluded that Japan is adhering to Article III, paragraph 5, of the Convention with regard to CITES trade in sei whales located in the North Pacific. As such, the Secretariat will not be taking any further action on the concerns you have raised'.

123. CITES Standing Committee, Summary Record of the 67th Meeting (Johannesburg, 23 September 2016), SC67 SR (2016), 7 (para 12).

124. Bodansky (n 98) 721-2 ('legitimacy - like trust more generally - is a fragile phenomenon. It is easier to destroy than to build up').

125. See generally F Biermann and A Gupta, 'Accountability and Legitimacy in Earth System Governance: A Research Framework' (2011) 70 Ecological Economics 1856-64 at 1858.

126. Reeve (n 71) 312, referring to earlier cases where infringements of the Convention by Japan and some European countries were quietly ignored ('a non-discriminatory approach demands similar treatment for all non-compliant states'). 